\title{
BIODEGRADABLE WASTE MANAGEMENT AS A PRACTICAL EXAMPLE OF GREEN ECONOMY
}

\author{
Adam PRZYSTUPA \\ KOM-EKO S.A., Lublin; adam.przystupa@gmail.com
}

\begin{abstract}
In 2015, 10,863 thousand tonnes of municipal solid waste were produced in Poland. It is estimated that approx. $50 \%$ of this volume consists of biodegradable waste. Due to its properties, such waste degrades swiftly and poses a threat and a burden to the environment. System solutions regarding the collection and management of biodegradable waste constitute an example of sustainable development and green economy owing to the development of green products, services, public procurement, investments, and jobs. The objective of the present paper is to analyse biodegradable waste management in light of green economy and the idea of sustainable development. Research method encompasses the analysis of literature and statistical data in relation to biodegradable waste management both in Poland and Lublin Province.
\end{abstract}

Keywords: sustainable development, green economy, biodegradable waste, recycling.

\section{The idea of sustainable development and green economy}

The turn of the $20^{\text {th }}$ century stimulated social sciences, especially economics, to reflect upon the expansive character of economic growth, which usually focuses upon maximisation of production, and ignores uncontrolled consumption of resources. The awareness of the limited character and deficit of natural resources resulted in anxiety regarding the growing burden on natural environment. In 1987, the World Commission on Environment and Development, also known as the Brundtland Commission, which was developed under the auspices of the UN, published a report entitled "Our Common Future". The report introduced the term sustainable development into public space and economic studies. The document highlighted the idea of population continuity and defined sustainable development as "development that meets the needs of the present without compromising the ability of future generations to meet their own needs" (Raport..., 1987, p. 41). 
The idea of sustainable development emerged as an answer to a broad spectrum of threats encompassing not only the degradation of environment, but also high demographic growth, inability to satisfy fundamental needs of a growing number of people, which resulted in the destabilisation of socio-economic systems. Therefore, the coexistence of three fundamental elements: economy, societies, and environment, was highlighted. Their effective coexistence is possible only in case limited resources are consumed reasonably (Szyja, 2015). The limited ability of the global ecosystem to renew its resources, along with the fundamental needs of societies, necessitate the application of a rolling costs analysis. As a consequence, one of the definitions of sustainable development determines that it is "the pursuit of ensuring all present and future generations access to sufficiently high ecological, economic, and socio-cultural standards regarding environment protection by the application of intra- and intergenerational equity" (Rogall, 2010).

Unfortunately, even though the implementation of sustainable development has become vital and constitutes a token of responsibility for future generations, its materialisation has only been declarative in character. The difficulty in dissemination of the idea results from both low awareness among populations, and lack of sufficient global involvement of individual states and businesses. Such globalism seems to be the key aspect of the issue. It results in the emergence of practical problems in the application of the concept at a local level e.g. in communes (Godlewska, 2014). As a consequence, the idea of green economy seems to be a more pragmatic approach to the matter (Burchard-Dziubińska, 2014). The term appeared in the report titled "Blueprint for a green economy" commissioned by the British government in 1989, and popularised in 2008 by the United Nations Environment Programme (UNEP). Green economy serves to improve human well-being, social equity, and decrease threats to the natural environment and ecological shortages. The following constitute its elements (Szyja, 2015):

- green products and services - those meeting specific environmental standards, thus noninvasive to the environment,

- green investments - efficient or sustainable in terms of energy and resources,

- green sectors of economy - environment-friendly technologies, renewable energy, etc.,

- green public procurement - directing public procurement towards the purchase of goods and services with limited impact upon the natural environment,

- green jobs - jobs contributing to restricting the consumption of natural resources, reduction of greenhouse gases and limiting the amount of waste and pollution.

Green economy does not replace sustainable development. By emphasising three elements: resource efficiency, low emission, and social inclusion, it makes the concept more concrete and practical. It is also believed that green economy is not a goal itself, but a tool enabling sustainable development to be achieved (Ryszawska, 2013). It can be said that it is an answer to the weakness of sustainable development, i.e. the lack of operationability and particular objectives along with means they can be achieved in. In case of green economy, particular emphasis is placed upon a shift of investments (both public and private), along with political 
actions supporting these, towards actions limiting emission, improving energy and resource efficiency, but also those preventing the loss of biodiversity of ecosystems. The increase of income and employment, along with the decrease of poverty, are to be achieved by such means.

\section{Biodegradable waste management as an element of green economy}

The general understanding of the idea of green sectors of economy is usually narrowed down to actions associated with the production of renewable energy. Meanwhile, due to the fundamental role of the natural environment in the idea of green economy and sustainable development, the sector of environment protection, especially waste management, plays a critical role as well.

Waste, due to its quantity, physical, and chemical properties, constitutes one of the most considerable threats to the environment. Due to its accumulation, chemical cycling is altered, agricultural and forest areas diminished, soil and waters polluted microbiologically, and gases emitted into the atmosphere (Łabuz, and Łabuz, 2005). Biodegradable waste is significant in this respect. Due to its physical and chemical properties, it degrades swiftly and poses epidemiological threats and burdens to environment.

The Council's directive 1999/31/EC on the landfill of waste defines biodegradable waste as any waste that is capable of undergoing anaerobic or aerobic decomposition, such as food and garden waste, and paper and cardboard (Dyrektywa Rady 1999...). Figure 1 presents a detailed classification of waste.

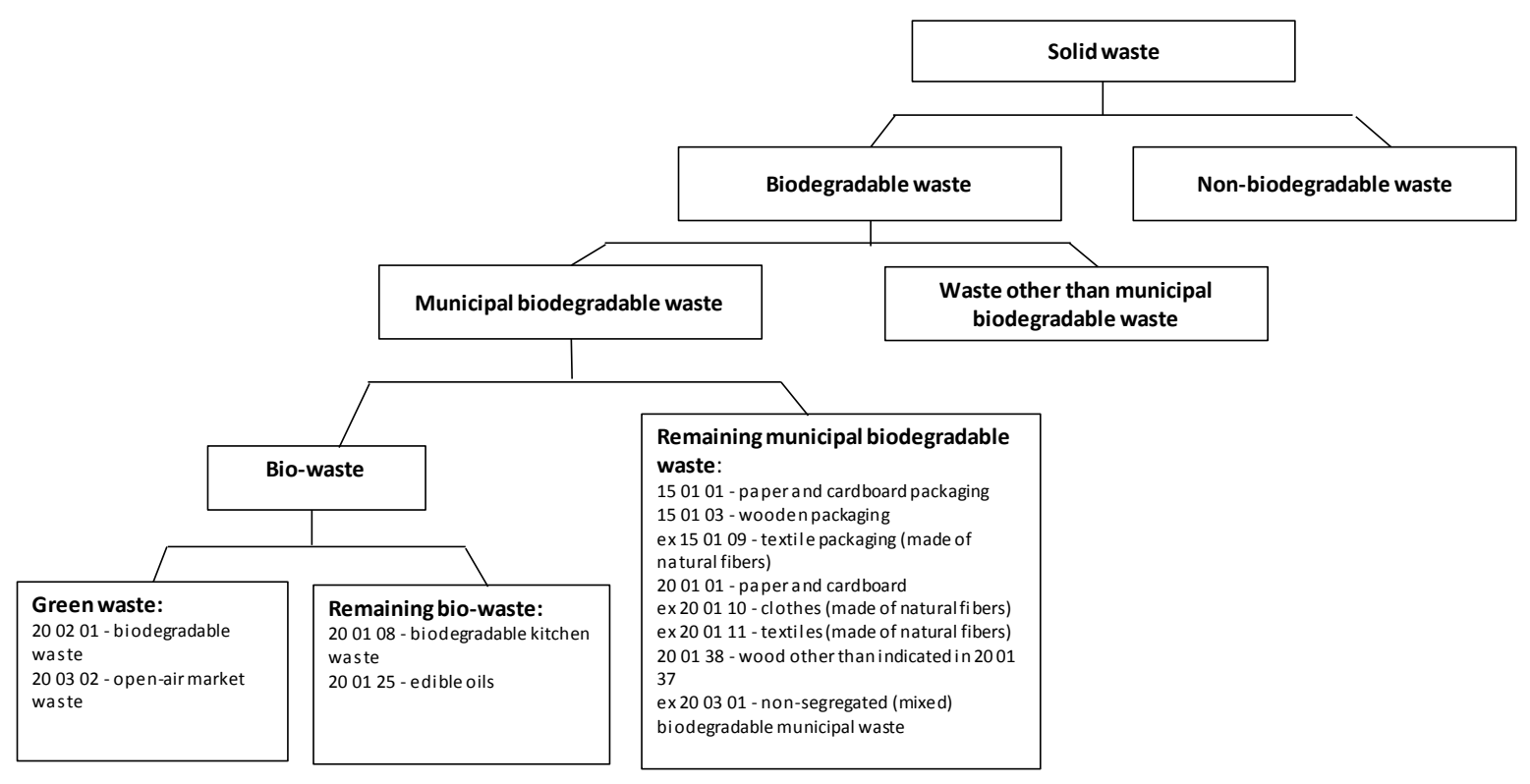

Figure 1. Classification of biodegradable waste. Note. Own study. 
Biodegradable waste attracts particular interest of the EU with regard to sustainable development. However, actions aiming at restricting its negative impact upon the ecosystem were taken much earlier. The directive 75/442/EEC adopted in July 1975 declared that "member states shall take the necessary measures to ensure that waste is recovered or disposed of without endangering human health and without using processes or methods which could harm the environment, and in particular: without risk to water, air or soil, or to plants or animals" (Dyrektywa Rady 75...). Such declarations materialised with the publication of the Council's directive 1999/31/EC on the landfill of waste in April 1999.

The fact that even though landfill constitutes the oldest and most practiced waste management method, it is the least harmful to the environment, ought to be stressed. It is mainly due to the presence of organic substances which undergo physical, chemical, and biological processes associated with methane and $\mathrm{CO}_{2}$ emission. It is estimated that methane originating from landfills constitutes $3-4 \%$ of the annual greenhouse gas emission. At the same time, methane absorbs infrared radiation 60 times more than $\mathrm{CO}_{2}$, which has been popularised in media as the cause of the greenhouse effect" (Klimek et al., 2010).

Therefore, the fact that the directive obliges member states to develop national strategies aiming to decrease the quantity of biodegradable waste to be stored, does not come as a surprise. Actions were to be taken in order to reduce the quantity in consecutive years to strictly defined levels in relation to the base year 1995 (Dyrektywa Rady 1999...). In parallel, the waste directive of 2008 introduces regulations obliging member states to collect bio-waste selectively in order to ensure its subsequent recycling (Dyrektywa Parlamentu...).

Actions taken in the framework of green economy constitute an alternative to landfill storage of biodegradable waste:

- green services in terms of selective collection of biodegradable waste,

- green public procurement regarding collection and management of waste encompassing the treatment of waste ensuring ecosystem's protection,

- green investments generating green jobs in biodegradable waste processing installations, e.g. those composting or methanising selectively collected green waste, or mechanical and biological installations processing mixed solid municipal waste,

- green products in the form of composts (fertilizers and soil-improving agents) originating from selectively collected green waste, and heat and electricity obtained in methanisation of biodegradable waste. 


\section{Collection and management of biodegradable waste in Poland}

In $2015,10,863$ thousand tonnes of municipal solid waste were produced in Poland. This means that each resident contributed to creating $283 \mathrm{kgs}$ of solid waste (Założenia...). When compared with other EU states, the number is insignificant. In 2014 a statistical Pole created $268 \mathrm{kgs}$ of waste, which ranked the country last but one among EU neighbours (see Figure 2). In addition, the $268 \mathrm{kgs}$ constituted merely $56.42 \%$ of the total quantity of waste created by an average resident of the Community. To some extent, it is a result of differences in the economic development of Poland and "old EU members". The scale of the discrepancy seems to suggest that it stems from incorrect reporting, lack of system solutions regarding its verification, and primarily, a result of purposeful understatement of the quantity of waste by businesses (den Boer, 2013) (non-registered waste disposal at illegal landfills in order to reduce disposal costs).

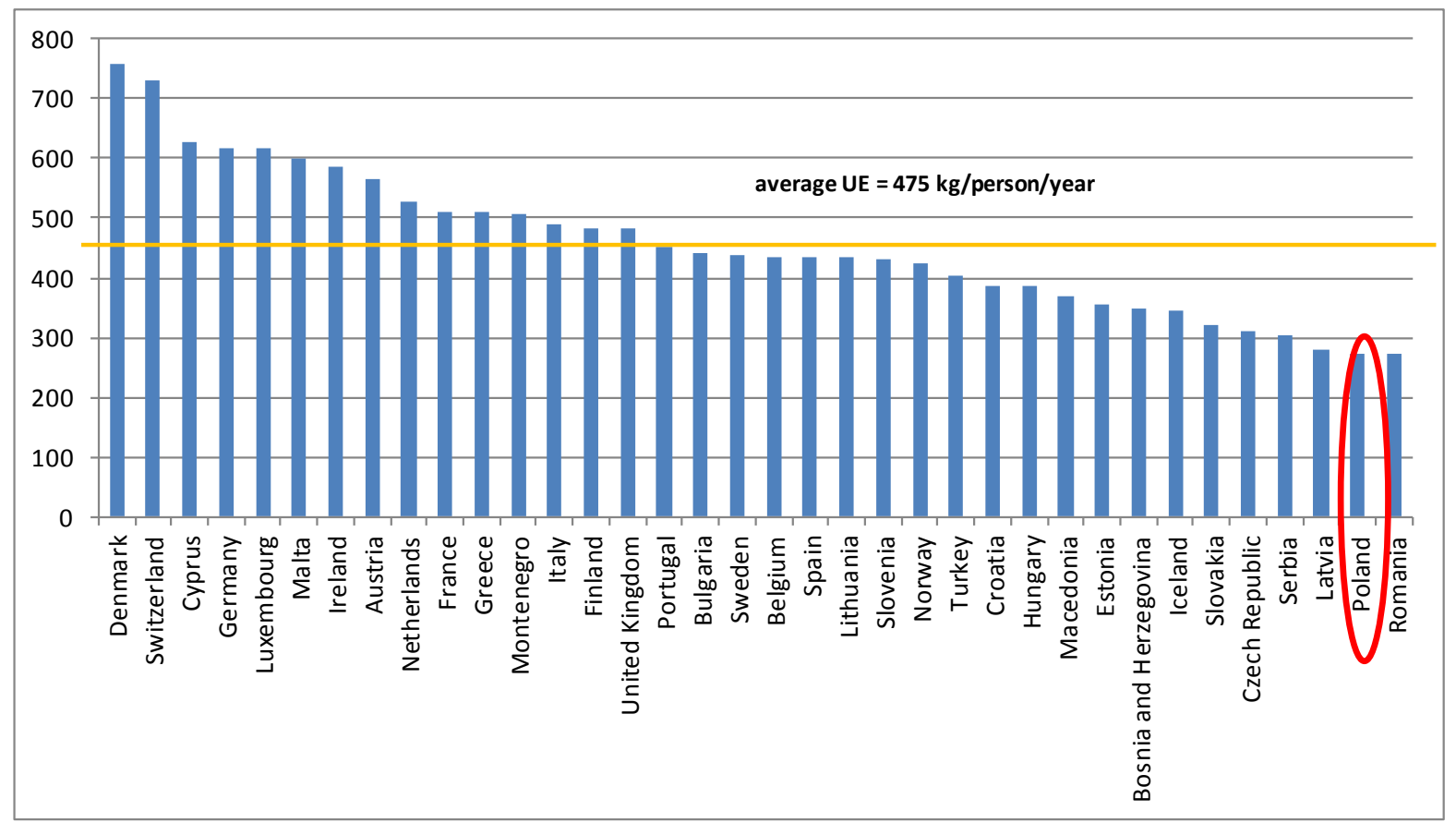

Figure 2. The quantity of municipal waste per resident in 2014 [kg/person/year]. Note. Own study on the basis of EUROSTAT (Municipal Waste Statistic).

In light of the above, an attempt at establishing both the quantity of municipal solid waste produced in Poland and the total quantity of such waste is fraught with the same risk. Due to the lack of a common selective waste collection system (except green waste), the majority is collected in the form of mixed municipal waste. When assessing its share in non-segregated waste, we are forced to follow the morphology of the waste, which, unfortunately, has not been systematised in Poland. As a consequence, assuming a 50.96\% (Jędrczak, 2010) share of 
biodegradable waste in municipal waste, approx. 5,536 thousand tonnes of organic waste are produced in Poland per annum.

Due to communes being granted the so-called ownership of waste, it was these organisations which were burdened with preparations towards the so-called garbage revolution (Założenia...) and its implementation. The commune organises waste collection and management in their respective areas. In addition, it is responsible for meeting waste management objectives, especially those regarding limits for biodegradable waste storage being met.

The authors of the new system of municipal waste management developed mechanisms embedded in the structure which are to facilitate the realisation of these new obligations:

1. regions of municipal waste management were introduced. Such a region may be composed of neighbouring communes with a total population of at least 150 thousand residents, or a commune with a population above 500 thousand (Ustawa o odpadach..., art. 35, ust. 5);

2. the division into individual regions of municipal waste management along with the establishment of regional installations is determined in provincial waste management plans (Ustawa o odpadach..., art. 35, ust. 4);

3. Regional Municipal Waste Treatment Plants (Regionalne Instalacje Przetwarzania Odpadów Komunalnych (RIPOK)) were defined as operating as waste treatment plants with the capacity to process waste originating from the region with a population of at least 120 thousand, and which meet state-of-the-art criteria, especially those applying to novel waste treatment technologies, or ensuring (Ustawa o odpadach..., art. 35, ust. 6);

a) mechanical and biological treatment of mixed municipal waste;

b) selective treatment of collected green and other bio-waste, and recycling it into products of fertilizing or crop-yielding character;

c) storage of waste originating from mechanical and biological treatment of mixed municipal waste and post-sorting-municipal-waste remains;

4. transregional municipal waste treatment plants were defined as those operating as incineration plants with the capacity of processing municipal waste collected in a region with a population of at least 500 thousand, and meeting state-of-the-art criteria (Ustawa o odpadach..., art. 35 , ust. 6a);

5. a ban on collecting mixed municipal waste and green waste outside the area they were produced in. Therefore, such waste needs to be processed in indicated regional plants. The ban excludes reloading stations and municipal waste selective collection stations (Ustawa o odpadach..., art. 23, ust. 2, 10, 11);

6. a ban on collecting mixed municipal waste and green waste outside the region (Ustawa o odpadach..., art. 23, ust. 3);

7. a ban on processing mixed municipal waste, green waste, and post-sorting-municipalwaste and mechanical and biological processing remains to be stored, outside the region 
(Ustawa o odpadach..., art. 20, ust. 7) - this excludes mixed waste to be incinerated in transregional plants (Ustawa o odpadach..., art. 20, ust. 10);

8. obligation to direct green and mixed waste directly to regional plants, and obligation for managers of selective collection stations to direct green waste directly to regional plants (Ustawa o utrzymaniu..., art. 9e, ust. 1, pkt. 2; Ustawa o utrzymaniu..., art. 9ea, ust. 2);

9. obligation for communes to establish the selective collection station with easy access for all residents of the commune and one which would ensure the collection of selectively collected green waste (Ustawa o utrzymaniu..., art. 3, ust. 2, pkt. 6; Ustawa o utrzymaniu..., art. 3, ust. 2a);

10. obligation for communes to establish selective collection of municipal waste in their areas, which would encompass biodegradable municipal waste, among others (Ustawa o utrzymaniu..., art. 3, ust. 2, pkt. 5).

The system was supplemented with "sealing" regulations introduced by the Minister of Economy in the regulation on the admission of waste to be stored (Rozporządzenia...). The ban on storing mixed municipal waste in landfills was enforced on $23^{\text {rd }}$ January 2015. As a consequence, attempts at managing waste by bypassing regional plants were curbed.

After three and a half years the new municipal waste management system has been in operation, conclusions on its efficiency for biodegradable waste management may be drawn. Primarily, an increase of selectively collected biodegradable waste ought to be noted (see Table 3 ). In 2013, which inaugurated the operation of the system, a $54.63 \%$ growth in the quantity of the waste was observed. The phenomenon was seen as a consequence of easy access to bags and containers. In the consecutive year, the quantity of collected biodegradable waste grew by $87.20 \%$. It proved the evolution of the system but also the quantity of such waste which had not been previously registered. In 2015, the growing trend continued (even though the scale was crippled by climatic factors impacting vegetation - approx. $12 \%$ decline in precipitation). The fact that only $53 \%$ of local governments collected biodegradable waste from their residents in that year is noteworthy (Wierzbowska-Kujda). In the majority of communes, biodegradable waste was collected via the selective waste collection stations. However, the fact that such collection is limited to selective collection of green waste is noteworthy.

\section{Table 1.}

Selective biodegradable waste collected in 2007-2015

\begin{tabular}{|l|r|c|c|c|c|c|c|c|c|}
\hline \multicolumn{1}{|c|}{ Specification } & $\mathbf{2 0 0 7}$ & $\mathbf{2 0 0 8}$ & $\mathbf{2 0 0 9}$ & $\mathbf{2 0 1 0}$ & $\mathbf{2 0 1 1}$ & $\mathbf{2 0 1 2}$ & $\mathbf{2 0 1 3}$ & $\mathbf{2 0 1 4}$ & $\mathbf{2 0 1 5}$ \\
\hline $\begin{array}{l}\text { Total municipal } \\
\text { waste [thousand } \\
\mathrm{Mg} \text { ] }\end{array}$ & $10,082.6$ & $10,036.4$ & $10,053.5$ & $10,040.1$ & $9,827.6$ & $9,580.9$ & $9,473.8$ & $10,330.4$ & $10,863.5$ \\
\hline $\begin{array}{l}\text { Selectively } \\
\text { collected } \\
\text { biodegradable } \\
\text { waste [thousand } \\
\text { Mg] }\end{array}$ & 85.2 & 123.1 & 164.2 & 181.3 & 210.0 & 201.6 & 311.8 & 583.7 & 657.1
\end{tabular}




\begin{tabular}{|l|r|r|r|r|r|r|r|r|r|}
\hline $\begin{array}{l}\text { Annual growth of the } \\
\text { quantity of biodegradable } \\
\text { waste [\%] }\end{array}$ & $-44.57 \%$ & $33.31 \%$ & $10.45 \%$ & $15.85 \%$ & $-4.00 \%$ & $54,63 \%$ & $87.20 \%$ & $12.57 \%$ \\
\hline $\begin{array}{l}\text { Share of selectively } \\
\text { collected biodegradable } \\
\text { waste in municipal waste }\end{array}$ & $0.84 \%$ & $1.23 \%$ & $1.63 \%$ & $1.81 \%$ & $2.14 \%$ & $2.10 \%$ & $3.29 \%$ & $5.65 \%$ & $6.05 \%$
\end{tabular}

Note. Own study on the basis of data from the Central Statistical Office of Poland.

Similar conclusions can be reached when analysing data concerning selective collection of green waste in three sectors of Lublin between July 2013 and November 2016, i.e. after the garbage revolution was implemented. The data is compiled in Table 4. 2014 witnessed a significant growth of the collected waste $(46.04 \%$ between July and December in relation to respective months in 2013). In 2015, the situation stabilised (11.10\% when compared with 2014). The data covering 2016 indicate a surprising and considerable growth in the quantity of the collected green waste (18.79\% when compared with 2015$)$. The phenomenon ought to be considered as the outcome of the system's learning.

Table 2.

Quantity of green waste selectively collected between July 2013 and December 2016 in three sectors of Lublin

\begin{tabular}{|r|r|r|r|r|r|r|r|r|r|r|r|r|r|}
\hline \multirow{2}{*}{ Year } & \multicolumn{10}{|c|}{ Quantity of green waste selectively collected in individual months [Mg] } & \multirow{2}{*}{ Total } \\
\cline { 2 - 13 } & $\mathbf{1}$ & $\mathbf{2}$ & $\mathbf{3}$ & $\mathbf{4}$ & $\mathbf{5}$ & $\mathbf{6}$ & $\mathbf{7}$ & $\mathbf{8}$ & $\mathbf{9}$ & $\mathbf{1 0}$ & $\mathbf{1 1}$ & $\mathbf{1 2}$ & \\
\hline 2013 & & & & & & & 148.9 & 156.4 & 166.6 & 431.0 & 468.2 & 55.9 & $1,426.9$ \\
\hline 2014 & 0.0 & 0.0 & 0.0 & 276.6 & 268.1 & 255.3 & 284.8 & 241.9 & 276.5 & 482.4 & 609.5 & 188.9 & $2,883.8$ \\
\hline 2015 & 56.1 & 45.5 & 127.4 & 221.1 & 320.8 & 323.6 & 230.4 & 137.9 & 213.3 & 339.5 & 860.0 & 328.5 & $3,204.0$ \\
\hline 2016 & 13.2 & 41.4 & 137.1 & 315.2 & 378.3 & 369.1 & 317.4 & 371.5 & 316.4 & 462.0 & 918.4 & 166.1 & $3,806.1$ \\
\hline
\end{tabular}

Note. own study on the basis of data from KOM-EKO S.A.

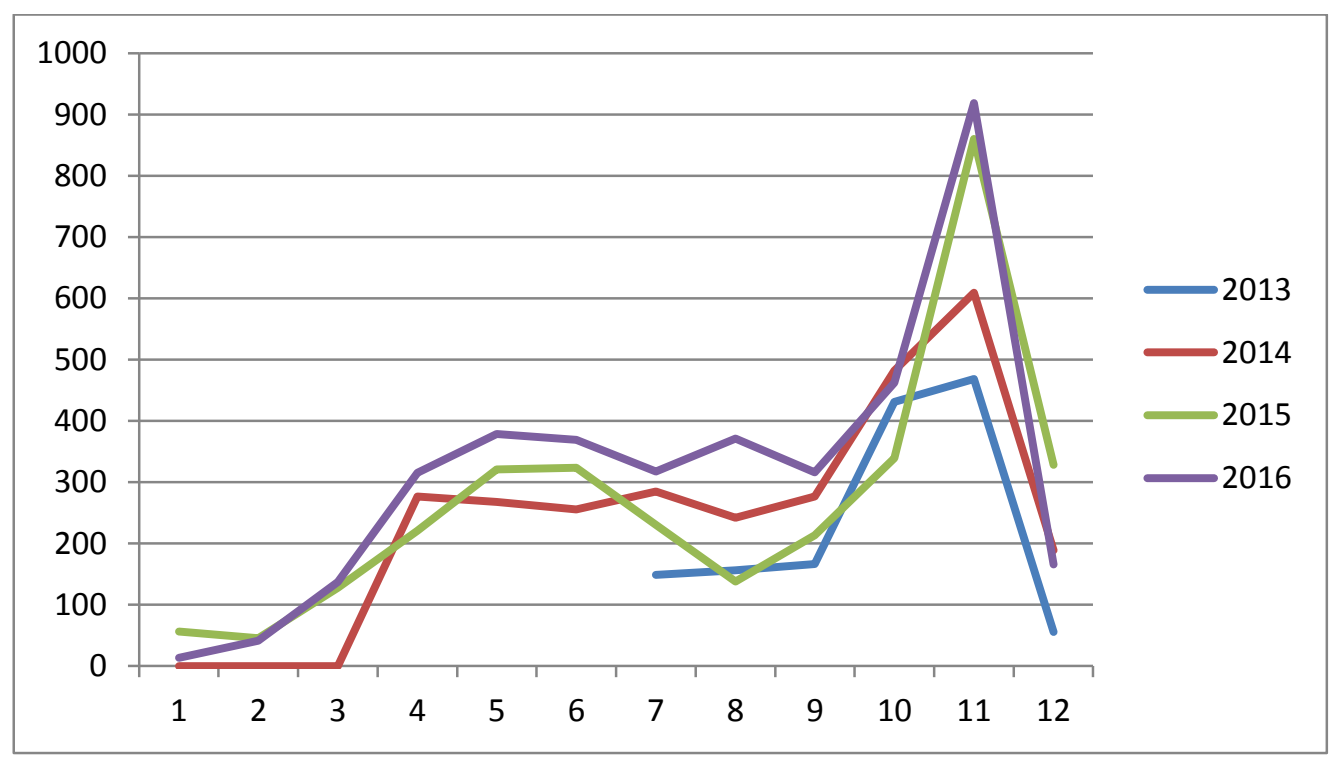

Figure 3. Seasonal changes in selective collection of green waste between July 2013 and November 2016 in three selected sectors of Lublin. Note. Own study. 
The increase in the selective collection of biodegradable waste resulted in the increase of the waste being biologically treated (see table 5). In 2015, 1,750 thousand tonnes of waste were composted or fermented, which constitutes a 55\% growth when compared with 2012 - the year preceding the introduction of new systemic solutions. At the same time, the share of anaerobic and aerobic waste management among all means of waste treatment in Poland increased in the respective period from $11.77 \%$ to $16.11 \%$. In accordance with the 2022 National Waste Management Plan, such processes were conducted in (valid for 31.12.201.):

- 97 plants for treatment of selectively collected biodegradable waste with the total processing capacity of $873,213 \mathrm{Mg}$ per annum;

- 127 mechanical and biological plants for treatment of mixed municipal waste with the total nominal biological processing capacity of 4,100,017 Mg.

Table 3.

Methods of municipal waste processing methods applied in Poland between 2011 and 2015 [in thousands of tonnes]

\begin{tabular}{|c|c|c|c|c|c|c|c|c|c|c|}
\hline $\begin{array}{c}\text { Waste } \\
\text { processing } \\
\text { methods }\end{array}$ & \multicolumn{2}{|c|}{2011} & \multicolumn{2}{|c|}{2012} & \multicolumn{2}{|c|}{2013} & \multicolumn{2}{|c|}{2014} & \multicolumn{2}{|c|}{2015} \\
\hline Recycling & 1,119 & $11.39 \%$ & 1244 & $12.98 \%$ & 1499 & $15.82 \%$ & 2180 & $21.10 \%$ & 2867 & $26.39 \%$ \\
\hline $\begin{array}{l}\text { Composting or } \\
\text { fermenting }\end{array}$ & 1.644 & $16.73 \%$ & 1128 & $11.77 \%$ & 1230 & $12.98 \%$ & 1154 & $11.17 \%$ & 1750 & $16.11 \%$ \\
\hline $\begin{array}{c}\text { Thermal } \\
\text { processing }\end{array}$ & 98 & $1.00 \%$ & 51 & $0.53 \%$ & 766 & $8.09 \%$ & 1560 & $15.10 \%$ & 1439 & $13.25 \%$ \\
\hline Storage & 6.967 & $70.89 \%$ & 7158 & $74.71 \%$ & 5979 & $63.11 \%$ & 5437 & $52.63 \%$ & 4808 & $44.26 \%$ \\
\hline $\begin{array}{l}\text { Total collected } \\
\text { waste }\end{array}$ & 9,828 & $100 \%$ & 9,581 & $100 \%$ & 9,474 & $100 \%$ & 10,331 & $100 \%$ & 10,864 & $100 \%$ \\
\hline
\end{tabular}

Note. Own study on the basis of data from the Central Statistical Office of Poland.

Therefore, the assessment of the system's efficiency regarding the reduction in the quantity of biodegradable waste to be stored seems valid. On the basis of the 2022 National Waste Management Plan, it can be observed that in 2013, Poland reduced the quantity of biodegradable waste by $40 \%$. In 2014 , the result was even better, and the reduction amounted to $35 \%$. In both cases, the reduction mandated by regulations was achieved. In addition, in 2014 , the reduction foreseen to be met on $16^{\text {th }}$ July 2020 was met.

The data compiled in Table 6 indicate even higher results. It was at the onset of the system's operation that the result foreseen for 2020 was achieved. Results regarding regional outcomes are more diversified - in 2013-2014, one in nine regions did not meet the mandated reduction.

Table 4.

Reduction of biodegradable waste quantity achieved in Lublin Province between 2012 and 2015

\begin{tabular}{|l|r|r|r|r|}
\hline \multicolumn{1}{|c|}{ Region } & \multicolumn{1}{c|}{$\mathbf{2 0 1 2}$} & $\mathbf{2 0 1 3}$ & $\mathbf{2 0 1 4}$ & \multicolumn{2}{|c|}{$\mathbf{2 0 1 5}$} \\
\hline Biała Podlaska & 28.50 & 30.10 & 20.23 & 8.86 \\
\hline East-Central & 50.20 & 39.80 & 30.21 & 28.74 \\
\hline Central & 52.40 & 44.60 & 12.59 & 19.19 \\
\hline
\end{tabular}




\begin{tabular}{|l|r|r|r|r|} 
Chełm & 24.90 & 12.00 & 16.63 & 13.48 \\
\hline South-Western & 42.60 & 26.70 & 21.39 & 23.47 \\
\hline Southern & 27.40 & 34.50 & 28.46 & 30.47 \\
\hline North-Western & 31.90 & 27.20 & 28,91 & 23.50 \\
\hline Puławy & 60.70 & 33.60 & 31.99 & 29.70 \\
\hline Zamość & 53.10 & 55.20 & 63.19 & 8.24 \\
\hline Lublin Province & $\mathbf{4 0 . 2 0}$ & $\mathbf{3 2 . 2 0}$ & $\mathbf{2 8 , 3 0}$ & $\mathbf{2 0 . 6 3}$ \\
\hline Required level & $\mathbf{7 5 . 0 0}$ & 50.00 & 50.00 & 50.00 \\
\hline
\end{tabular}

Note. Own study.

Even though such surprisingly good results stem from the composition of the indicator determining the level of reduction, with the present saturation of regions with biodegradable waste processing plants, Poland's meeting the mandated requirements remains uncompromised. Although stabilising processes conducted in mechanical and biological mixed municipal waste treatment plants offer the greatest contribution to outcomes, the fact that constant improvement of selectively collected biodegradable waste management ought to be a necessity, must be highlighted. The declared processing capabilities of national plants exceed the nominal quantity of waste collected in 2015 by $32.87 \%$. However, individual provinces and regions suffer a deficit of free processing capabilities.

In light of the requirements placed by EU pertaining to circular economy, a question if such results are satisfactory, arises. The postulated $10 \%$ limit on municipal waste storage to be achieved in 2030 seems concerning. The fact that in $2015,44.26 \%$ of municipal waste was stored in landfills ought to be kept in mind. This has been the most effective result in history. However, it is far from the objective to be achieved in the perspective of merely 14 years. The rate of reduction may be misleading- over the past 5 years, the share of stored waste decreased by $5.33 \%$ per annum. The rate resulted from the development of processing plants (238 plants with the total processing capacity of 3,334.6 thousand $\mathrm{Mg}$ in 2010, and 340 plants with the total capacity of $13,129.9$ thousand $\mathrm{Mg}$ in 2014). In subsequent years, a decline will surely be observed. Therefore, the achievement of the reduction foreseen for 2030 will be impossible without changes in collection and treatment methods. When the fact that mixed waste constitutes the dominant fraction in municipal waste $(76.64 \%$ in 2015$)$, and the fact that biodegradable waste in the form of kitchen waste constitutes the majority of mixed waste, is considered, it seems that the development of selective collection of such waste seems to be the target solution. Such an approach will facilitate the effective biological treatment of such waste in order for fertilising agents to be produced instead of stabilising biodegradable fractions in mechanical and biological processes and storing these (at least $35 \%$ of mixed municipal waste is mechanically and biologically processed and then stored). The first step has been made in the regulation of the Minister of Environment on detailed means of selective collection of selected fractions, which introduced the obligatory container for biodegradable waste (Rozporządzenie...).

The development of biodegradable waste selective collection seems to be a significant tool in achieving the second objective of the circular economy, i.e. $60 \%$ of municipal waste to be 
recycled in 2025 and 65\% in 2030 (Komunikat..., 2015). According to the 2022 National Waste Management Plan, the following recycling levels were achieved: $22 \%$ in 2013 , and $26 \%$ in 2014. In light of these figures, the level of 50\% mandated in 2020 and $70 \%$ postulated for 2030 , seem challenging and difficult to materialise. On the one hand, segregation and selective collection of biodegradable waste will improve the quality and efficiency of recycling packaging waste. On the other hand, this will increase the volume of organic waste which may be recycled. It requires a system of selective collection of kitchen waste to be developed and a network of plants processing such waste into fertilising agents to be improved.

\section{Conclusions}

To conclude, when reviewing the state of biodegradable waste management in Poland, the following ought to be considered:

- municipal waste management, especially the biodegradables, which constitutes an element of green economy, forms a vital element of actions aiming to implement the idea of sustainable development;

- biodegradable waste attracts particular attention of the European Commission due to the fact that methane created in decomposition processes in landfills constitutes $3-4 \%$ of annual greenhouse gas emission;

- the new system of waste management implemented in Poland in 2013 generates green products and services, green public procurement, green investments and jobs;

- the implementation of the new system of waste management based upon common and ready access of residents to the collection of municipal waste resulted in the growth of the quantity of selectively collected green waste. In 2015, the collection of green waste was three times higher than in the base 2012 which preceded the implementation of the system. The tendency is constant;

- the share of selectively collected green waste in the total quantity of collected municipal waste increased from $2.10 \%$ in 2012 to $6.05 \%$ in 2015 despite the fact that organised waste collection was conducted by only $53 \%$ of communes;

- the share of biological waste treatment processes in plants in Poland was higher in 2015 when compared with the base 2012 by $4.33 \%$. At the same time, the share of waste stored was lower by $30.45 \%$;

- the development of regional municipal waste treatment plants ought to be considered as an element of green investments and green jobs creation, and was reinforced by the ban on mixed municipal waste storage. With regards to the present calculation methodology, it ensures Poland meets the EU quota of reducing storage of biodegradable waste - the quota required in 2020 was met in 2014; 
- Poland's meeting EU regulations regarding the idea of circular economy in 2030, both in case of municipal waste recycling $(65 \%)$ and the reduction of the quantity of waste stored (10\%), will be impossible without the intensification of selective biodegradable waste collection (especially kitchen waste) and development of a network of plants organically recycling such waste. Biological processing modules of mechanical and biological plants seem to be applicable in such cases. Such actions ought to result in the increase of biodegradable waste being recycled and the emergence of a synergy effect regarding quality improvement and a boost of packaging recycling.

\section{Bibliography}

1. den Boer, E. (2013). Nowy system gospodarki odpadami wraz z diagnoza stanu obecnego. Opracowanie dla potrzeb Podkomisji Stałej do Spraw Monitorowania Gospodarki Odpadami przy Komisji Ochrony Środowiska, Zasobów Naturalnych i Leśnictwa, Wrocław.

2. Burchard-Dziubińska, M. (20134). Wdrażanie zielonej gospodarki jako odpowiedź Unii Europejskiej na trudności rozwojowe. Acta Universitatis Lodziensis, Folia Oeconomica, Vol. 3(303).

3. Dyrektywa Rady 75/442/EWG z dnia 15 lipca 1975 r. w sprawie odpadów.

4. Dyrektywa Rady 1999/31/WE z dn. 26 kwietnia 1999 r. w sprawie składowania odpadów.

5. Dyrektywa Parlamentu Europejskiego i Rady 2008/98/WE z dn. 19 listopada 2008 r. w sprawie odpadów oraz uchylająca niektóre dyrektywy.

6. Godlewska, J. (2014). Rozwój zielonej gospodarki na szczeblu lokalnym - wybrane aspekty. Zeszyty Naukowe Uniwersytetu Szczecińskiego, Studia i Prace Wydziału Nauk Ekonomicznych i Zarządzania, nr 37, t. 2.

7. Jędrczak, A. (2010). Analiza dotyczaca ilości wytwarzanych oraz zagospodarowanych odpadów ulegających biodegradacji. Zielona Góra: Ministerstwo Środowiska.

8. Klimek, A., Wysokiński, L., Zawadzka-Kos, M., Osęka, M., and Chrząszcz, J. (2010). Poradnik metodyczny w zakresie PRTR dla składowisk odpadów komunalnych - synteza. Warszawa: NFOŚiGW.

9. Komunikat Komisji do Parlamentu Europejskiego, Rady Europejskiego Komitetu Ekonomiczno-Społecznego i Komitetu Regionów (2015). Zamknięcie obiegu - plan działania UE dotyczacy gospodarki o obiegu zamkniętym, 2 grudnia 2015 r., COM(2015) 614 final.

10. Łabuz, B., and Łabuz, J. (2005). Oznaczanie morfologii odpadów komunalnych na przykładzie odpadów pochodzących z terenu Jaworzna. Prace Naukowe GIG Górnictwo i Środowisko, nr 4, Katowice: Główny Instytut Górnictwa. 
11. Raport of the World Commission on Environment and Development (1987). Our Common Future. Oslo.

12. Rogall, H. (2010). Ekonomia zrównoważonego rozwoju. Teoria i praktyka, Warszawa: Zysk i S-ka.

13. Rozporządzenie Ministra Środowiska z dn. 29 grudnia 2016 r. w sprawie szczegółowego sposobu selektywnego zbierania wybranych frakcji (DzU. 2017, poz. 19).

14. Rozporządzenia Ministra Gospodarki w sprawie rodzajów odpadów, które mogą być składowane na składowiskach odpadów w sposób nieselektywny z dn. 16 stycznia 2015 r. (DzU. z 2015 r. poz.110).

15. Ryszawska, B. (2013). Zielona gospodarka w dokumentach strategicznych Unii Europejskiej. Ekonomia i Środowisko, $n r$ 3(46).

16. Szyja, P. (2015). Zielona gospodarka w Polsce - stan obecny i perspektywy. Nierówności Społeczne a Wrost Gospodarczy, $n r 41$.

17. Wierzbowska-Kujda, M. Niewykorzystany potencjał bioodpadów. Available online: http://www.teraz-srodowisko.pl/aktualnosci/Niewykorzystany-potencjal-bioodpadow1324.html, accessed 17.03.2017.

18. Ustawa o odpadach z dn. 14 grudnia 2012 r. (DzU. 2016, poz. 1987).

19. Ustawa o utrzymaniu czystości i porządku w gminach z dn. 13 września 1996 r. (DzU. 1996 nr 132, poz. 622 z póź. zm.).

20. Założenia do projektu ustawy o zmianie ustawy o utrzymaniu czystości i porządku w gminach i niektórych innych ustaw. Available online https://www.mos.gov.pl/g2/big/ 2010_05/4071a5cc181d11031d688527aaa9a22b.pdf, accessed 17.03.2017.

21. http://ec.europa.eu/eurostat/statistics-explained/index.php/Municipal_waste_statistics\# Database, accessed 17.03.2017.

22. http://stat.gov.pl/obszary-tematyczne/srodowisko-energia/srodowisko/ochronasrodowiska-2016,1,17.html, accessed 09.12.2016. 